\title{
Inovasi Pelayanan Kesehatan Di Rumah Sakit Umum Daerah Kota Pariaman
}

\author{
${ }^{1}$ Bobi Rizki Ananda, ${ }^{2}$ Roni Ekha Putera, ${ }^{3}$ Ria Ariany \\ ${ }^{123}$ Jurusan Administrasi Publik, Fakultas Ilmu Sosial dan Ilmu PolitikUniversitas Andalas \\ Padang, Indonesia \\ Email ${ }^{1}$ Bobirizkiananda2@gmail.com, ${ }^{2}$ roniekhaputera@ soc.unand.ac.id, ${ }^{3}$ uja.ujaku@ gamil.com \\ Received: 11 Februari 2020; Revised: 23 Februari 2020; Accepted: 26 Februari 2020
}

\begin{abstract}
This study aims to explain service innovations in the health sector that have been carried out by the Pariaman District General Hospital so that the services provided to the community are better. So far what has happened in the city is the presence of bad services performed by various existing hospitals in the regions so that there are people who complain about these health services. This study uses qualitative research methods with data collection techniques through interviews, observation and documentation. The informants came from the hospital and the community who performed the service. The results of this study indicate that the Pariaman Regional General Hospital has been innovating as a form of effort of the Pariaman Regional General Hospital in facilitating matters of service to the community, with the existence of innovations in the Pariaman Regional General Hospital since 2018, the quality of services has increased, things this is proven by the Community Satisfaction Index (IKM) in 2018 which is outstanding value.
\end{abstract}

Keyword: Public Service; Service Innovation; Public Health

\begin{abstract}
Abstrak
Penelitian ini bertujuan untuk menjelaskan inovasi-inovasi pelayanan di bidang kesehatan yang telah dilakukan oleh Rumah Sakit Umum Daerah Pariaman sehingga pelayanan yang diberikan kepada masyarakat menjadi lebih baik. Selama ini yang terjadi di masyarakat adalah terdapatnya pelayanan buruk yang dilakukan oleh berbagai rumah sakit yang ada di daerah. Sehingga dengan demikian ada masyarakat yang mengeluhkan pelayanan kesehatan tersebut. Penelitian ini menggunakan metode penelitian kualitatif dengan Teknik pengumpulan data melalui wawancara, observasi dan dokumentasi. Informan berasal dari pihak rumah sakit dan masyarakat yang melakukan layanan. Adapun hasil dari penelitian ini menunjukkan bahwa Rumah Sakit Umum Daerah Pariaman telah melakukan inovasi sebagai bentuk upaya Rumah Sakit Umum Daerah Pariaman dalam mempermudah urusan pelayanan kepada masyarakat. Dengan adanya inovasi di Rumah Sakit Umum Daerah Pariaman tersebut semenjak tahun 2018, kualitas pelayanan semakin meningkat, hal ini dibuktikan dengan Indek Kepuasan Masyarakat (IKM) pada tahun 2018 yang bernilai sangat baik.
\end{abstract}

Kata kunci: Pelayanan Publik; Inovasi Pelayanan; Pelayanan Kesehatan

Link DOI : http://dx.doi.org/10.31314/pjia.8.2.167-179.2019 


\section{PENDAHULUAN}

Di era keterbukaan informasi sekarang ini pelayanan kesehatan yang bermutu dan akuntabel menjadi suatu hal yang penting, sehingga memberikan keleluasaan bagi masyarakat untuk dapat merasakan kenyamanan dalam menerima layanan. Untuk itu pemerintah berusaha menciptakan kondisi kesehatan yang lebih baik di masa yang akan datang dengan cara mencanangkan beberapa program pelayanan kesehatan. Adapun programprogram yang dimaksud adalah berupa adanya bantuan subsidi pembiayaan kesehatan, peningkatan sumber daya manusia di sektor kesehatan, peningkatan sumber daya obat dan perbekalan kesehatan, pemberdayaan masyarakat, serta perbaikan manajemen kesehatan. Tujuan program-program tersebut adalah untuk meningkatkan aksesibilitas penduduk (terutama penduduk miskin) pada pelayanan kesehatan dasar. (Usman dkk, 2010).

Hal yang bertolak belakang terjadi dari usaha pemerintah tersebut dimana ada kendala dalam usaha peningkatan akses kesehatan yang dimiliki oleh masyarakat miskin misalnya terkait dengan adanya lokasi dari sejumlah sarana dan prasarana kesehatan (seperti Puskesmas, rumah sakit, rumah bersalin, apotek, toko obat, praktik dokter dan sebagainya) yang kerap kali berada di lokasi yang sulit diakses oleh penduduk miskin. Akibatnya terjadi kesejangan pelayanan kesehatan, dalam artian penduduk yang tergolong kurang mampu (miskin) memperoleh pelayanan kesehatan lebih buruk daripada mereka yang tergolong mampu (kaya). Adapun lokasi fasilitas kesehatan bukanlah satusatunya faktor penyebab kesenjangan terjadi di bidang pelayanan kesehatan. Ada
Faktor-faktor lain misalnya kemampuan keuangan, adanya ketersediaan peralatan kesehatan, jumlah tenaga medis maupun paramedik yang kurang mencukupi, akses informasi tentang kondisi kesehatan, serta adanya jaringan bisnis di sektor kesehatan memiliki pengaruh yang signifikan terhadap kesenjangan pelayanan kesehatan. Namun rendahnya aksesibilitas penduduk miskin terhadap fasilitas kesehatan adalah salah satu faktor determinan yang mempengaruhi terjadinya kesenjangan pelayanan kesehatan. (Usman, dkk, 2010).

Di Indonesia penyedia jasa dibidang kesehatan belum menghasilkan perbaikan dalam beberapa aspek untuk meningkatkan mutu pelayanan yang berkualitas, pelayanan kesehatan di Indonesia masih terbilang belum berjalan dengan baik (Antaranews.com, 2020). Permasalahan ini disebabkan oleh reformasi politik dalam tubuh pemerintah masih belum diikuti oleh reformasi birokrasi, maka dengan demikian pemerintah juga memikirkan kualitas pelayanan dalam pemenuhan kebutuhan masyarakat.

Permasalahan lainnya seperti yang dikemukakan oleh Bata dkk (2013) dari beberapa variabel yang dikemukakan terdapat variabel hubungan empaty antara perawat dengan pasien, disebutkan bahwa sebagian besar pasien puas dengan pelayanan yang diberikan, dan sebagian kecil pasien tidak puas dengan pelayanan, hal ini disebabkan beberapa pasien mengeluh terhadap pelayanan petugas yang membeda-bedakan status sosial, ditemukan bahwa sebagian orang saja yang mendapat perhatian khusus dan mendapat pelayanan ekstra saat dirawat dirumah sakit tersebut.

Sama halnya dengan penelitian yang dilakukan oleh Konli (2014) dari hasil 
pengamatan dan penelitian yang dilakukan di Puskesmas Desa Gunawan menunjukkan bahwa pelayanan kesehatan kepada masyarakat didaerah tersebut belum sepenuhnya berjalan dengan baik, hal ini disebabkan: petugas pelayanan datang kurang tepat waktu, disiplin pegawai masih kurang, jumlah petugas kesehatan yang tidak sesuai dengan jumlah pasien yang datang, sarana dan prasarana yang kurang sehingga kondisi demikian membuat masyarakat kurang puas dengan pelayanan yang diberikan.

Lebih lanjut mendukung dari temuan tersebut di atas, dijelaskan lagi bahwa permasalahan-permasalahan pelayanan kesehatan di Indonesia juga tidak luput dari ideology yang dianut oleh aparatur negara, hal ini didasari oleh Kementerian Kesehatan Republik Indonesia yang menggulirkan 7 Reformasi Pembangunan Kesehatan yaitu: 1) revitalisasi pelayanan kesehatan, 2) ketersediaan, distribusi, dan mutu sumber daya manusia, 3) mengupayakan ketersediaan, distribusi, keamanan, mutu, efektivitas, keterjangkauan obat, vaksin dan akses, 4) jaminan kesehatan, 5) keberpihakan kepada daerah tertinggal perbatasan dan kepulauan(dtpk) dan daerah bermasalah kesehatan (dbk), 6) reformasi birokrasi, 7) Word class health care.

Bila dicermati dari ketujuh reformasi ini terdapat ideologi berbasis pasar dan sosialis, dijelaskan bahwa butir keberpihakanpemerintah pada daerah tertinggal dan pemerataan mencerminkan adanya ideologi sosial liberal,namun "world class health care" cenderung berbasis pada intervensi pemerintah terhadap pasar dengan cara memberikan subsidi agar mampu bersaing dalam pasar kesehatan Asia Tenggara yang semakin bebas (Trisnantoro, 2010), dan ini sangat berpengaruh terhadap pedoman penetapan kebijakan dan pelaksanaan dalam penataan birokrasi di Indonesia.

Beralih dari hal tersebut berbicara tentang Trade off reformasi pelayanan kesehatan yang implikasinya berupa ekuiti, mutu, dan efisiensi, dijelaskan sebagian reformasi sistem pelayanan kesehatan telah bergerak kearah sosialisme dan kapitalisme, akan tetapi rekomendasi trade off ini pentingnya ditetapkan dahulu "tujuan akhir" reformasi system pelayanan kesehatan di Indonesia oleh Stakeholderbeserta pemangku kepentingan, dan kemudian baru disusun road map atau langkah-langkah kecil yang flisibel untuk menetapkan tujuan akhir (Siswanto, 2010), sehingga reformasi pelayanan kesehatan di Indonesia bisa tercapai.

Mendukung hal tersebut di atas, dalam upaya peningkatan kualitas pelayanan yang diberikan dibidang kesehatan pemerintah telahmengeluarkan ketentuan bagi setiap rumah sakit milik pemerintah untuk memiliki Standar Pelayanan Minimal (SPM) (Peraturan Pemerintah No 65, 2010). SPM adalah ketentuan mengenai jenis dan mutu pelayanan dasar yang merupakan urusan wajib daerah yang berhak diperoleh setiap warga secara minimal, SPM itu berupa jenis-jenis pelayanan yang akan diberikan kepada masyarakat dengan memiliki tolak ukur yang jelas untuk tiap jenis pelayanan. SPM merupakan janji yang akan dipenuhi oleh pihak rumah sakit dalam memberikan pelayanan kepada masyarakat, SPM mempunyai dua elemen yaitu indikator kinerja dan target yang harus dicapai, maka perlu disusun dengan tiga alasan menurut Kuntjoro, dkk (2010) yaitu (1) peraturan perundang-undangan menghendaki demi

Copyright (c) 2019, Publik (Jurnal Ilmu Administrasi), ISSN: 2301-573X (Print), ISSN: 2581-2084 (Online) 


\section{Available Online at http://journal.umgo.ac.id/index.php/Publik \\ Publik (Jurnal Ilmu Administrasi) Vol 8 (2), December 2019}

menjamin akuntabilitas pelayanan publik, (2) pasien sebagai fokus pelayanan membutuhkan dan menhendaki pelayanan yang berkualitas, memuaskan, dan dapat dijamin memberikan keamanan dan (3) untuk menjadi BLU, rumah sakit harus dapat menunjukkkan akuntabilitas kinerjanya dengan ditetapkannya indikator dan target pencapaian tiap indikator kinerja.

Berdasar penjelasan sebelumnya, kebijakan kesehatan telah menuntut adanya perubahan kearah yang lebih baik lagi dalam melakukan pelayanan kepada masyarakat secara efektif dan efisien, salah satu daerah yang juga sudah berupaya dalam mewujudkan kebijakan kesehatan tersebut adalah Provinsi Bali dengan menggalakkkan pelayanan kesehatan bagi warga kurang mampu melalui kebijakan JKBM (Jaminan Kesehatan Bali Mandara). Dimana pemerintah sudah meningkatkan anggaran dalam program JKBM akan tetapi kualitas obat, sarana dan prasana perlu ditata ulang kembali (Widynyani, 2015), hal ini menunjukkan walaupun perbaikan kualitas pelayanan publik bukanlah sesuatu yang mudah, dalam implementasinya masih banyak kekurangan yang perlu penyempurnaan, akan tetapi pemerintah Provinsi Bali telah mengupayakan melakukan reformasi untuk mencapai tatakelola pemerintahan daerah yang baik (Good Governance).

Untuk mencapai good governance dengan kepuasan masyarakat terhadap pelayanan yang diberikan, Depertemen Kesehatan Indonesia juga menekankan pada pentingnya kualitas pelayanan kesehatan yang lebih baik, karena mengingat rumah sakit sebagai salah satu saran penyedia layanan kesehatan yang sudah menjadi kebutuhan pokok masyarakat sebagai fasilitas mutlak yang harus ada dan mencukupi kebutuhan masyarakat baik dari kuantitas maupun kulitas pelayanan yang diberikan. Dengan semakin meningkatnya demand masyarakat akan kualitas pelayanan kesehatan maka pelayanan kesehatanyang diberikan rumah sakit harus ditingkatkan agar lebih efektif dan efisien dengan tetap memperhatikan mutu, prinsip serta kelayakan dan etika pelayanan kesehatan, sebab kualitas pelayanan merupakan suatu bentuk penilaian konsumen (pasien) terhadap tingkat pelayanan yang diterima dengan tingkat layanan yang diharapkan (Azrul. 1996).

Undang-Undang No 36 tahun 2009 tentang kesehatan pada pasal 53 ayat 2 menyangkut mengenai pemerintah dan pemerintah daerah juga bertanggung jawab atas penyelenggaraan pelayanan kesehatan. Dengan demikian, maka hak dan kewajiban masyarakat dalam melakukan urusan kesehatan akan dilindungi oleh pemerintah, sehingga apapun yang berhubungan dengan urusan pelayanan dirumah sakit, pemerintah maupun aparatur birokrat dapat memberikan pelayanan yang berkualitas dan menempatkan diri sebagai pelayan bagi masyarakat. Salah satu contoh misalnya Rumah Sakit Daerah. Rumah Sakit Umum Daerah (RSUD) selama ini sering sekali diidentik dengan buruknya birokrasi pelayanan kepada kepentingan masyarakat. Padahal pelayanan dibidang kesehatan yang dilakukan pada RSUD merupakan bagian dari pelayanan publik yang sifatnya urgen untuk diperhatikan, dan salah satu penyedia jasa dibidang kesehatan adalah pemerintah, namun ternyata reformasi politik dalam tubuh pemerintah belum diikuti oleh reformasi birokrasi sehingga 
belum layak menghasilkan perbaikan dalam hal kualitas pelayanan (Dwiyanto, 2002). Padahal masyarakat setiap waktu selalu menuntut perlu adanya pelayanan publik yang berkualitas dari birokrasi/ pemerintah, meskipun apa yang dituntut oleh masyarakat sering tidak sesuai dengan kenyataan yang terjadi di lapangan. Masyarakat cenderung diposisikan sebagai pihak yang ingin mendapatkan pelayanan bukan sebagai pihak yang dilayani, padahal sebagai agen pemerintah seharusnya pihak rumah sakit memberikan pelayanan yang terbaik kepada masyarakat.

Disamping itu hal yang menjadi perhatian utama dalam pelayanan di RSUD adalah front liner yang berada dibagian garda terdepan saat pertama kali melayanai masyarakat. Front line staff ini menjadi sangat penting karena merekalah yang memberikan pelayanan secara langsung kepada masyarakat dan salah satu indikator diperoleh masyarakat dari unit penyelenggara layanan publik salah satunya rumah sakit. (Ariany dkk, 2013). Front liner dibagian garda terdepan juga sangat menentukan image akan perubahan yang dilakukan dalam sebuah RSUD, sebab interaksi pembuka pelayanan akan membentuk moment of truth atau kesan pertama yang dijumpai oleh masyarakat sebelum melakukan interaksi jauh besar lagi di RSUD. Maka Seringkali ini belum menjadi perhatian bagi RSUD yang ada, bahwa front liner belum menjadi acuan untuk dikembangkan potensinya, hal ini ditemukan dalam penelitian sebelumnya bahwa front liner di RSUD tidak memiliki motivasi yang tinggi dalam melaksanakan tugasnya dalam pelayanan publik (Ariany, dkk, 2018). untuk mengetahui kualitas pelayanan yang

RSUD adalah institusi pelayanan kesehatan yang menyelenggarakan pelayanan kesehatan perorangan secara paripurna yang menyediakan pelayanan rawat inap, rawat jalan dan gawat darurat (UU R1 NO 44 Tahun 2009). Provinsi Sumatera Barat juga ikut andil dalam melakukan pelayanan kesehatan sesuai dengan amanat UUD 1945, hal ini tercermin dalam Peraturan Gubernur (Pergub) Sumatera Barat No 91 Tahun 2012 tentang Sistim Pelayanan Jaminan Kesehatan Sakato Sumatera Barat, dalam tujuan Pergub tersebut dijelaskan bahwa pemerintah daerah akan menjamin akses pelayanan bagi seluruh penduduk dengan mencegah beban biaya kesehatan yang melebihi kemampuan penduduk untuk membayar, artinya masyarakat Sumatera Barat yang ekonomi dibawah rata-rata tidak akan terbebani dan tidak perlu takut untuk berobat kerumah sakit.

RSUD di Provinsi Sumatera Barat merupakan perangkat organisasi pelayanan yang dimiliki oleh pemerintah daerah, dan sebagai rumah sakit yang sudah berstatus Badan Layanan Umum Daerah (BLUD) (Inspektorat.Sumbarprov.go.id). Terdapat 4 RSUD yang menjadi milik pemerintah Provinsi Sumatera Barat, yaitu Rumah Sakit Umum Daerah ( RSUD ) Solok, Rumah Sakit Ahmad Muctar Bukittinggi (RSAM), Rumah Sakit Umum (RSUD ) Pariaman, dan Rumah Sakit Jiwa (RSJ) HB Saanin.

Dari keempat rumah sakit tersebut, RSUD Pariaman merupakan rumah sakit yang sudah berbenah kearah yang lebih baik, ditinjau dari segi kualitas dan kuantitas yang mempuni disegala bidang, baik sumber daya maupun faktor penyokong berupa sarana dan prasarana. Selain itu RSUD Pariaman menjadi RSUD

Copyright @ 2019, Publik (Jurnal Ilmu Administrasi), ISSN: 2301-573X (Print), ISSN: 2581-2084 (Online) 


\section{Available Online at http://journal.umgo.ac.id/index.php/Publik}

Publik (Jurnal Ilmu Administrasi) Vol 8 (2), December 2019

Percontohandalam segi bidang pelayanan kepada masyarakat, hal tersebut dikarenakan banyak sekali perubahan yang dilakukan oleh pihak rumah sakit dengan mengarah pada role model pembangunan. Dengan menggalakkan visi sebagai 'Rumah Sakit Regional Yang Berstandar Internasional dengan Nilai Islami', maka diantara upaya yang dilakukan oleh Rumah Sakit adanya ketersedian informasi yang lengkap melalui Websitenya http://rsudpariaman.sumbarprov.go.id/ seb agai bentuk dari akuntabilitas dan transparansi, dengan mengeluarkan motto " Jika Bisa Terbuka Ngapain Tertutup”. Dengan adanya website tersebut, segala bentuk pelaporan kegiatan (Lakip) maupun anggaran yang dialokasikan beserta ketersediaan tempat tidur untuk rawat inap dan lain sebagainya bisa dengan mudah masyarakat untuk melihatnya, lebih lanjut konten yang tertera di website tersebut juga sudah banyak data atau fitur penunjang yang lengkap.

Hal tersebut mencerminkan bahwa RSUD Pariaman juga telah mendukung kebijakan kesehatan dengan mempermudah pelayanan yang diberikan kepada masyarakat, dengan hal perubahan yang dilakukan oleh RSUD Pariaman membuktikan bahwa RSUD Pariaman mendapatkan penghargaan, sukses meraih prestasi AKREDITASI KARS versi 2012 dengan Prediket Paripurna Dari Komisi Akreditasi Rumah Sakit Pusat (Jurnalsumbar.com), mengingat akan penghargaan yang diterima oleh RSUD Pariaman maka banyak inovasi dan temuan yang telah dilakukan oleh RSUD Pariaman mencerminkan bahwa RSUD Pariaman sudah mampu mendukung birokrasi, karena pokok -pokok dari pemaknaan birokrasi tersebut adalah suatu bentuk reformasi birokrasi yang merupakan perubahan terencana yang dilakukan secara cermat terhadap birokrasi publik, adanya perencanaan strategis yang jelas kurun waktunya, dilakukannya inovasi temuan baru yang segar, inovatif dan lain sebagainya (Safroni, 2012). Inovasi menjadi penting dalam hal pelayanan publik, misalnya inovasi pelayanan yang menggunakan teknologi informasi sehingga dapat meningkatkan efisiensi dan efektivitas dalam memberikan pelayanan (Jalma dkk, 2019). Artinya dengan adanya inovasi pelayanan yang telah muncul di daerah-daerah telah membawa perbaikan dalam praktek pelayanan publik, salah satunya di RSUD Pariaman sehingga diharapkan dapat menopang praktekperaktek good governance.

Dengan demikian penelitian ini penting dilakukan untuk bisa menjelaskan inovasi pelayanan kesehatan apa saja yang telah dilakukan oleh Rumah Sakit Umum Daerah Pariaman sehingga dalam memberikan pelayanan kepada masyarakat, sehingga dalam pengukuran indeks kepuasan masyarakat mampu memperoleh penilaian terbaik. Adapun tujuan dari penelitian ini adalah untuk menjelaskan inovasi-inovasi pelayanan kesehatan yang dilakukan oleh Rumah Sakit Umum Daerah Pariaman dalam rangka meningkatkan pelayanan kesehatan.

\section{METODE PENELITIAN}

Penelitian ini dilakukan selama 3 bulan (dari bulan Maret-Mei 2019) di RSUD Pariaman, Provinsi Sumatera Barat, RSUD Pariaman merupakan salah satu tempat dari 4 unit RSUD milik pemerintah yang sudah berstatus Badan Layanan Umum Daerah (BLUD). Pendekatan yang dipergunakan dalam Penelitian ini adalah 
kualitatif dengan tipe penelitian Deskriptif. Adapun alasan peneliti mengunakan metode penelitian kualitatif ini adalah dikarenakan penelitian ini ingin menjelaskan inovasi-inovasi yang sudah dilakukan oleh RSUD Pariaman dalam peningkatan kepuasan masyarakat dalam layanan kesehatan. Informan dalam penelitian ini ditentukan dengan purposive sampling yaitu teknik penentuan sampel dengan pertimbangan tertentu (Sugiyono, 2007). Adapun informan dalam penelitian ini adalah pihak rumah sakit (direktur, kepala bagian, dokter, perawat, analis labor) dan Masyarakat (keluarga pasien). Adapun Teknik pengumpulan pengumpulan data digunakan teknik wawancara, observasi dan dokumen (Usman, dkk, 2003).

\section{HASIL DAN PEMBAHASAN}

Menurut Permen PAN dan RB Nomor 30 Tahun 2014 Tentang Pedoman Inovasi Pelayanan Publik, Inovasi pelayanan publik adalah terobosan jenis pelayanan baik yang merupakan gagasan/ide kreatif original dan/atau adaptasi/modifikasi yang memberikan manfaat bagi masyarakat, baik secara langsung maupun tidak langsung, dengan artian inovasi bukan sesuatu penemuan yang baru melainkan dengan menata ulang kembali sistem kearah yang lebih baik.

Ada juga mengatakan inovasi bukan hal yang baru ditempat organisasi lain, akan tetapi inovasi merupakan produk baru ditempat organisasi yang dijalankan, karena belum ada sebelumnya yang melakukan perubahan dimana tempat sebuah organisasi bekerja, seperti halnya banyak jenis-jenis dan level inovasi. Menurut Muluk Inovasi berbicara mengenai 5 kateria yaitu inovasi produk layanan, inovasi proses pelayanan, inovasi metode pelayanan, inovasi sitem pelayanan dan inovasi kebijakan (Muluk, 2008). Maka demikian untuk lebih jelasnya inovasi yang sudah diterapkan di RSUD Pariaman dalam melakukan pelayanan kepada pasiennya, dalam penelitian ini inovasi yang dimaksud meliputi inovasi dari Halvorsen yang mengatakan inovasi dapat dikategorikan kedalam 3 kelompok yaitu Incramental Innovations-radical innovation, Top-down innovations-bottom up innovation, dan Needd Led Innovation and Efficiency-led Innovation (Suwarno, 2008)., berikut dipaparkan hasil penelitian tersebut sebagai berikut:

\section{Incramental Innovations-radical innovation}

Inovasi ini ditandai dengan tingkat perubahan yang terjadi, perbaikan inkramental yang dilakukan berupa perbaikan produk dan proses pelayanan yang sebelumnya sudah ada. perubahan dari produk layanan yang semula semi aktif manjadi proaktif dalam layanan kepada masyarakat, hal tersebut dibuktikan dengan adanya layanan langsung kepada tiap-tiap poli tanpa harus ada proses pengantrian. Seperti hal inovasi yang dilakukan oleh RSUD Pariaman, menurut Direktur RSUD Pariaman tersebut Indria Velutina mengatakan bahwa sepanjang tahun 2019, penyakit yang paling banyak yang ditampung oleh RSUD Pariaman adalah penyakit radang paru-paru dengan jumlah pasiennya mencapai 309 orang (KlipPositif.com), pesien tersebut tidak hanya berasal dari Kota Pariaman namun juga Kabupaten Pariaman, Kab Agam, dan Kab. Pasaman Barat, sehingga jumlah kunjungan pasien dari tahun sebelumnya meningkat dari 8.227 orang menjadi 8.919 orang.

Copyright @ 2019, Publik (Jurnal Ilmu Administrasi), ISSN: 2301-573X (Print), ISSN: 2581-2084 (Online) 
Dari hal tersebut tercermin bahwa RSUD pariaman merupakan rujukan dari daerah lain dan mengambarkan kualitas yang dilakukan oleh RSUD Pariaman sudah sangat baik. Untuk melihat kondisi yang demikian, Diantara upaya yang dilakukan oleh Rumah Sakit Umum Daerah Pariaman menuju reformasi adalah adanya inovasi baru bagi pasien rawat jalan yaitu berupa informasi teknologi baru atau sebagai bentuk terobosan, dimana pihak rumah sakit mengadakan penjadwalan bagi pasien rawat jalan. Artinya pasien rawat jalan tidak perlu datang kerumah sakit pagi-pagi untuk mengambil nomor antrian, malahan cukup dengan melalui internetan di rumah.

Dari gambar (Gambar 1) dapat dilihat bahwa aplikasi yang dibentuk bisa membuat sebuah pekerjaan menjadi efektif dan efisien, proses kerja dari inovasi yang diciptakan tersebut dimalai dari syarat pendaftaran pada pukul 15.00-3.59 WIB untuk kunjungan dihari berikutnya, setelah mendapatkan konfirmasi, pasien langsung ke poliklinik tujuan pada esok harinya.

Selain itu, ada juga inovasi yang dibuat oleh RSUD Pariaman, yaitu RSUD Pariaman berhasil membuat Inovasi yang diberi nama PELURU PASIF (Pelayanan Pasien TB Paru Terpadu dan Komprehensif) yaitu inovasi pelayanan pasien TB Paru yang berkunjung ke poli Paru Rsud Pariaman dengan nama peluru Pasif Tujuan dari inovasi ini adalah untuk meningkatkan kepatuhan pasien dalam berobat, kepatuhan minum obat serta untuk meningkatkan angka kesembuhan pasien, hal ini bermaksud agar pasien yang melakukan perawatan merasa sangat puas ketika berkunjung.

Ada juga inovasi yang dilakukan oleh pihak RSUD Pariaman adalah berupa
SI GADIS KOJA (Siap Tanggap Pasien Disabilitas, Lanjut Usia dan Resiko Jatuh). Program inovasi tersebut merupakan inovasi yang mengutamakan pelayanan khusus kapada pasien dengan keterbatasan diri berupa fisik, kognitif, mental sensorik, emosional. Pasien disabilitas ini tidak perlu lagi melakukan antrian seperti pasien lainnya dan mendapat pelayanan tidak terlalu lama. Inovasi-inovasi yang dilakukan oleh pihak RSUD Pariaman sebagai bentuk dari pembaharuan sistem kearah yang lebih baik lagi demi memudahkan masyarakat dalam melakukan pelayanan. Dengan demikian menuruk Muluk suatu inovasi dapat dikatakan sebagai inovasi produk layanan apabila mengalami modifikasi dari bentuk layanan sebelumnya untuk meningkatkan kualitas, citra, fungsi.

\section{Gambar 1 \\ Aplikasi Rawat Jalan RSUD Pariaman}

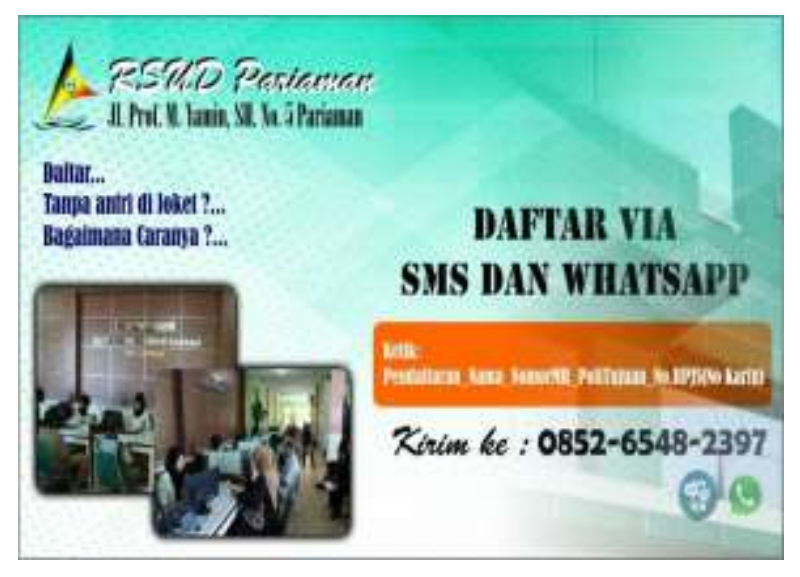

Sumber :

http://rsudpariaman.sumbarprov.go.id

\section{Top-down innovations-bottom up innovation,}

Inovasi ini menjelaskan siapa yang memimpin proses perubahan prilaku dalam sebuah organisasi. dimulai dari level top yang berarti manajemen atau organisasi yang lebih tinggi, sedangkan bottom merujuk pada tingkat bawah organisasi 
yang berarti pekerja atau pegawai. Di Indonesia unit penyelenggara kesehatan pada tingkat pertama (tingkat bawah) adalah puskesmas, sesuai dengan Peraturan Menteri Kesehatan RI No 75 Tahun 2014 Tentang Pusat kesehatan masyarakat. Hal ini berarti Puskesmas sebagai unit tingkat bawah juga melakukan prosedur dan cara bekerja dengan perubahan kearah yang lebih baik lagi.

Dari data yang ditemukan bahwa perubahan prilaku berupa pola interaksi dengan masyarakat secara tidak langsung Pihak RSUD sudah melakukan kotak suara dengan tiga penilaian yang sudah disediakan dimasing-masing ruangan, sehingga memudahkan masyarakat untuk menyampaikan keluhannya pada perawat maupun pihak rumah sakit yang bersangkutan. Sesuai data yang peneliti dapatkan kotak suara tersebut di buka sekali seminggu untuk melihat apa yang dibutuhkan masyarakat.

Pada masing-masing unit intalasi sudah dibentuk 1 orang komando yang menjadi penghubung antara unit satu dengan yang lain bahkan sampai ketingkat atas, tupoksi masing-masing sudah ada berdasarkan SOP yang dipegang pada setiap unit, artinya interaksi sistem yang mencakup cara baru atau yang diperbarui dalam berinteraksi dengan aktor-aktor lain atau dengan kata lain adanya perubahan dalam tata kelola pemerintahan (changes in governance) sudah berjalan dengan lancar. Sistem sendiri memiliki arti suatu kesatuan usaha yang terdiri dari bagian-bagian yang berkaitan satu sama lain yang berusaha mencapai suatu tujuan dalam suatu lingkungan kompleks (Marimin, dkk, 2006). Pengertian tersebut mencerminkan adanya beberapa bagian dan hubungan antar bagian, ini menunjukan kompleksitas dari sistem yang meliputi kerja sama antara bagian yang interdependen satu sama lain. Hal ini dimulai dari pendaftaran pasien sampai dengan keluarnya pasien dari rumah sakit, semua terkoneksi dengan satu jalur yang tiap-tiap ruangan sudah ada ada satu koordinator dalam melakukan pengawasan kepada pasien.

Pada dasarnya semua yang memimpin pada RSUD dikepalai oleh seorang Direktur, dan prosedur pelayanan sebelum memasuki garda terdepan yaitu rumah sakit terlebih dahulu terlebih dahulu pasien harus mendaftar di puskesmas terdekat sebelum merujuk ke rumah sakit, prosedur tersebut sudah diatur dalam UU Kesehatn Republik Indonesia, hal ini berarti rumah sakit juga harus bekerjasama dengan puskesmas sekitar guna untuk perbaikan prosedur layanan. Dengan hal tersebut RSUD Pariaman sekarang sudah mengalami kemajuan pesat dibuktikan dengan naiknya rating tipe RSUD Pariaman dari tipe $\mathrm{B}$ menjadi Tipe $\mathrm{C}$, hal tesebut membutikan RSUD Pariaman sudah bergerak kearah yang lebih baik lagi, padahal kalau dilihatuntuk mendapatkan akreditasi B tersebut sangatlah sulit, disebutkan bahwa di Provinsi Sumatera Barat terdapat 4RSUD yangsudahmendapatkan akreditasi $\mathrm{B}$, satu RSUD bertipe A, dan 23 RSUD bertipe C (Sumbarprov.go.id).

\section{Needd Led Innovation and Efficiency-led Innovation,}

Dalam hal ini mengatakan bahwa apakah inovasi dianggap mampu untuk menyelesaikan permasalahan yang terjadi atau inovasi yang dilakukan dapat meningkatkan efesiensi pelayanan, prosedur dan produk yang sudah ada sebelumnya.

Copyright (c) 2019, Publik (Jurnal Ilmu Administrasi), ISSN: 2301-573X (Print), ISSN: 2581-2084 (Online) 
Tabel 1

Survey Kepuasan Masyarakat pada Instansi Rawat Jalan RSUD Pariaman

\begin{tabular}{lllll}
\hline No & \multicolumn{1}{c}{ Poli } & Nilai & Mutu & Kinerja \\
\hline 1 & Fisioterapi & 93,15 & A & Sangat Baik \\
2 & Penyakit dalam & 91,63 & A & Sangat Baik \\
3 & Anak & 91,44 & A & Sangat Baik \\
4 & Paru & 93,7 & A & Sangat Baik \\
5 & Tht & 89,94 & A & Sangat Baik \\
6 & Jantung & 90,11 & A & Sangat Baik \\
7 & Orthopedic & 93,05 & A & Sangat Baik \\
8 & Psikologi tumbang & 9,45 & A & Sangat Baik \\
9 & Kebidanan & 90,57 & A & Sangat Baik \\
10 & Mata & 9,57 & A & Sangat Baik \\
11 & Jiwa & 91,38 & A & Sangat Baik \\
1 & Neurologi & 89,94 & A & Sangat Baik \\
13 & Bedah & 9,45 & A & Sangat Baik \\
14 & Urologi & 96,75 & A & Sangat Baik \\
15 & Gigi & 96,48 & A & Sangat Baik \\
16 & Kb & 97,75 & A & Sangat Baik \\
17 & Okupasi & 95,68 & A & Sangat Baik \\
18 & Kulit dan kelamin & 97,11 & A & Sangat Baik \\
\hline
\end{tabular}

Sumber : Laporan Kegiatan Survey Kepuasan Masyarakat Tahun 2018

Berdasarkan data yang telah diuraikan sebelumnya diatas dapat dirujuk bahwa inovasi yang dilakukan oleh Pihak RSUD mendapatkan respon yang sangat baik bagi masyarakat, hal ini berdasarkan survey kepuasan masyarakat yang dilakukan.

Berdasarkan data yang diperoleh, ketika program inovasi rawat jalan tersebut diberlakukan semenjak tahun 2018, kualitas pelayanan semakin meningkat, hal ini dibuktikan dari hasil penelitian Ariany dkk (2018) mengenai indeks kepuasan masyarakat pada tahun 2018 yang bernilai sangat baik. Dari tabel 1 dapat disimpulkan bahwa responden di Instalasi Rawat Jalan RSUD Pariaman sudah sangat puas. Hal ini terlihat dari penilaian dan hasil perhitungan SKM(Survey Kepuasan Masyarakat) pada tiap-tiap poli di Instalasi Rawat Jalan, menunjukkan RSUD Pariaman dengan mutu pelayanan A atau kinerja pelayanan Sangat Baik, hal tersebut tentu juga tidak terlepas dari dukungan tenaga kepegawaian yang ada di RSUD tersebut, berdasarkan data yang peneliti temukan tercatat jumlah tenaga RSUD Pariaman sebanyak 510 orang.

Berdasarkan data yang dipaparkan tersebut, hal ini juga sejalan dengan konsep yang dikemukakan oleh Halvorsen, menurutnya dalam suwarno inovasi tersebut dikategorikan sebagai Needd Led Innovation and Efficiency-led Innovation yaitu innovasi dapat meningkatkan efesiensi pelayanan dengan produk yang sudah ada sebelumnya, Dapat dilihat berdasarkan data yang peneliti temukan ketika program tersebut diluncurkan, ratarata kepuasan masyarakat menunjukkan sangat baik.

Dari tabel 1 dapat disimpulkan bahwa responden di Instalasi Rawat Jalan RSUD Pariaman sudah sangat puas. Hal ini terlihat dari penilaian dan hasil perhitungan SKM(Survey Kepuasan Masyarakat) pada 
tiap-tiap poli di Instalasi Rawat Jalan, menunjukkan RSUD Pariaman dengan mutu pelayanan A atau kinerja pelayanan Sangat Baik, hal tersebut tentu juga tidak terlepas dari dukungan tenaga kepegawaian yang ada di RSUD tersebut, berdasarkan data yang peneliti temukan tercatat jumlah tenaga RSUD Pariaman sebanyak 510 orang. Berdasarkan data yang dipaparkan tersebut, hal ini juga sejalan dengan konsep yang dikemukakan oleh Halvorsen, menurutnya dalam suwarno inovasi tersebut dikategorikan sebagai Needd Led Innovation and Efficiency-led Innovation yaitu inovasi dapat meningkatkan efesiensi pelayanan dengan produk yang sudah ada sebelumnya, Dapat dilihat berdasarkan data yang peneliti temukan ketika program tersebut diluncurkan, rata-rata kepuasan masyarakat menunjukkan sangat baik. Dengan demikian maka dalam tulisan ini dapat dijelaskan tentang inovasi yang dilakukan oleh RSUD Pariaman dalam memberikan pelayanan kepada masyarakat.

\section{PENUTUP}

\section{Kesimpulan}

Berdasarkan yang telah diuraikan sebelumnya, maka dapat disimpulkan bahwa dalam upaya untuk menghadapi semakin tingginya kebutuhan akan kesehatan, maka RSUD Pariaman sudah berbenah diri dalam melakukan pelayanan kesehatan kepada masyarakat. RSUD Pariaman telah berupaya memanfaatkan teknologi digital dengan berupaya menciptakan inovasi-inovasi yang memudahkan layanan kepada masyarakat sehingga urusan pelayanan dapat dilakukan secara efektif dan efisien. Adapun inovasiinovasi yang dilakukan antara lain berupa aplikasi rawat jalan, inovasi-inovasi yang dibentuk juga berupa adanya PELURU PASIF (Pelayanan Pasien TB Paru Terpadu dan Komprehensif), dan SI GADIS KOJA (Siap Tanggap Pasien Disabilitas, Lanjut Usia dan Resiko Jatuh). Dengan adanya Inovasi-inovasi yang telah dibuat dan dilakukan oleh RSUD Pariaman telah mampu memberikan kepuasan kepada masyarakat yang melakukan layanan kesehatan, hal ini dibuktikan dengan beberapa keberhasilan yang diperoleh oleh RSUD Pariaman mendapatkan indeks kepusan masyarakat (IKM) yang sangat baik.

\section{Saran}

Dalam peningkatan pelayanan kepada masyarakat, hendaknya perlu ada dukungan pemerintah daerah juga untuk mendukung inovasi yang dibuat oleh RSUD Pariaman. Sosialisasi melalui media cetak dan di berbagai media sosial diperlukan, sehingga masyarakat luas mengetahui inovasi pelayanan apa yang sudah dilakukan oleh pihak rumah sakit. Selanjutnya bagi pihak rumah sakit bisa menjadi pendorong agar terus berbenah kearah Role model pembangunan agar menjadi rumah sakit yang benar-benar menempatkan masyarakat sebagai warga negara yang berhak untukpenerima layanan. 


\section{DAFTAR PUSTAKA}

Ariany, Ria, Kusdarini dan R.E, Putera, (2018). Laporan Kegiatan Survey Kepuasan Masyarakat, Rumah Sakit Umum Daerah Pariaman Tahun Anggaran 2018. Lembaga Penelitian Dan Pengabdian Kepada Masyarakat LPPM Universitas Andalas

Ariany, Ria, Damsar dan R.E, Putera, (2018), model motivasi empat pilar: redisain perilaku layanan Front -liner dirumah sakit pemerintah dalam Komunitas Pembangunan dan Globalisasi, Padang, Erka, CV. Rumah Kayu Pustaka Utama bekerjasama dengan FISIP Unand.

Ariany, Ria, dan R.E, Putera (2013). Analisis Kinerja Organisasi Pemerintah dalam Memberikan Pelayanan Publik di Kota Pariaman. MIMBAR: Jurnal Sosial dan Pembangunan, 29(1), 33-40.

Azwar, Azrul. (1996), Pengantar Administrasi Kesehatan, Jakarta: Binarupa Aksara

Bata, Y, W, Alwy, Darmawansyah. (2013). Hubungan Kualitas Pelayanan Kesehatan dengan Kepuasan Pasien Pengguna Askes Sosial pada Pelayanan Rawat Inap di RSUD Lakipadada Kabupaten Tana Toraja [Laporan Penelitian]. Makassar: Universitas Hasanuddin

Dwiyanto, Agus, Dkk. (2002). Reformasi Birokrasi Publik di Indonesia, Yogyakarta, Pusat Studi Kependudukan dan Kebijakan (PSKK,) UGM

Jalma, H., R.E, Putera, dan Kusdarini, K. (2019). E-Government dengan Pemanfaatan Web OpenSID dalam Pelayanan Publik di Nagari Tanjung Haro Sikabu-kabu Padang Panjang. Publik (Jurnal Ilmu Administrasi), 8 (1), 24-37

Konli, Steven. (2014), Pelayanan Kesehatan Masyarakat di Puskemas Desa Gunawan Kecamatan Sesayap Kabupaten Tana Tidung. Jurnal Ilmu Pemerintahan. Vol 2 No 1 Tahun 2014

Kuntjoro, Tjahjono, dan Hanevi Djasri (2010), Standar Pelayanan Minimal Rumah Sakit Sebagai Persyaratan Badan Layanan Umum dan Sarana Peningkatan Kinerja. Vol 10, No 01.Tahun 2010

Marimin, Hendri Tanjung, Haryo Prabowo. (2006). Sistem Informasi Manajemen Sumber Daya Manusia. Jakarta: Grasindo.

Muluk. K. (2008). Knowledge Management, Kunci Sukses Inovasi Pemerintahan Daerah. Malang: Bayumedia

PERMENPAN dan RB Nomor 30 Tahun 2014 Tentang Pedoman Inovasi Pelayanan Publik

Peraturan Gubernur (Pergub) Sumatera Barat No 91 Tahun 2012 tentang Sistim Pelayanan Jaminan Kesehatan Sakato Sumatera Barat

Peraturan Pemerintah RI Nomor 65 Tahun 2005, Tentang Pedoman Penyusunan dan Penerapan Standar Pelayanan Minimal $(S P M)$

Safroni, Ladzi. (2012). Manajemen Dalam Reformasi Publik". 
Yogyakarta. ADITYA Media

Publishing,

SDP2D (Sistem DataBase Perencanaan

Pembangunan Daerah).

Sumbarprov.go.id

Siswanto. Analisis Trade-OffDalam

Reformasi Sistim Pelayanan

Kesehatan di Indonesia, Vol 13.

No 2, Tahun 2010

Sugiyono, (2007), Metode Penelitian

Administrasi. Bandung: CV.

Alfabeta

Sutopo, H.B. (2006), Metodologi Penelitian Kualitatif dasar teori dan Terapannya dalam Penelitian. Surakarta: Universitas Sebelas Maret

Suwarno, Yogi. (2008). Inovasi di Sektor Publik. Jakarta: STIA-LAN Press

Trisnantoro, Laksono. (2010). Ideology Apa Yang Dianut Oleh Kebijakan Kesehatan Di Indonesia, Vol. 13, No 04.

UU R1 NO 44 Tahun 2009 Tentang Rumah Sakit

Usman, Husaini, dan Purnomo Setiady Akbar. (2003). Metode Penelitian Sosial. Jakarta: Bumi Aksara

Usman, S., Widhyharto, D., \& Maika, A. (2010). Strategi Penciptaan Pelayanan Kesehatan Dasar untuk Kemudahan Akses Penduduk Desa Miskin. Jurnal Ilmu Sosial dan Ilmu Politik, 13(3), 306-323.

Widnyani, Ida Ayu Putu Sri. (2015). Administrative Reform In Health Services Through Bali Mandara Health Insurance (Jkbm) Towards Good Governance In Bali Province. Vol. 10, Nomor 2, ISSN. 1907-0489

Copyright @ 2019 , Publik (Jurnal Ilmu Administrasi), ISSN: 2301-573X (Print), ISSN: 2581-2084 (Online) 